\title{
Molecular Analysis in the Differentiation of Colletotrichum gloeosporioides Isolates from the Cashew and Mango Trees
}

\author{
Ilka Márcia Ribeiro de Souza Serra ${ }^{1 *}$, Maria Menezes ${ }^{1}$, Rildo Sartori Barbosa Coelho ${ }^{1}$, \\ Gabriela Moraes Guerra Ferraz ${ }^{2}$, Angélica Virginia Valois Montarroyos ${ }^{3}$ and Luiza Suely \\ Semem Martins ${ }^{2}$ \\ ${ }^{I}$ Fitossanidade; Departamento de Agronomia; Universidade Federal Rural de Pernambuco; R. Dom Manuel de \\ Medeiros, S/N; 52171-900; Recife - PE - Brasil. ${ }^{2}$ Genética; Departamento de Biologia; Universidade Federal \\ Rural de Pernambuco; 52171-900; Recife - PE - Brasil. ${ }^{3}$ Departamento de Ciências Biológicas; Universidade \\ Federal de Pernambuco; 50670-901; Recife - PE - Brasil
}

\begin{abstract}
The aim of the present work was to analyze the molecular methods in the differentiation of Colletotrichum gloeosporioides isolates obtained from the cashew and mango trees. The different molecular taxonomic methods used proved to be efficient regarding intraspecific characterization. Similarly, molecular methods also proved to be efficient in differentiation of the $\mathrm{C}$. gloeosporioides isolates in relation to host specificity. In the analysis of the ITS sequence of the ribosomal DNA, all the isolates amplified with the CgInt and ITS4 primers, confirming that they pertained to C. gloeosporioides. The results from this study suggested that methods based on the pathogenicity, isozyme analysis and RAPD were effective in differentiating C. gloeosporioides isolates from the cashew and mango trees.
\end{abstract}

Key words: Anacardium occidentale, anthracnose, ITS-rDNA, Mangifera indica

\section{INTRODUCTION}

Anthracnose in the cashew (Anacardium occidentale) and mango (Mangifera indica) trees is caused most often by Colletotrichum gloeosporioides (Penz.) Penz. \& Sacc., and is considered a disease of economic loss in the Northeast Brazil (Menezes and Hanlin, 1996a; Menezes and Hanlin, 1996b; Serra and Silva, 2004). C. acutatum J.H. Simmonds may also be the anthracnose agent in the mango trees (Freeman et al., 1998; Arauz, 2000). These species attack the leaves, branches, blossoms, stems and fruits, requiring periodic spraying with the fungicides in orchards and efficient post-harvest treatment (Ribeiro, 2005). The species cause varying degrees of harm depending on the susceptibility of the host plant and environmental conditions (Menezes, 2005; Ribeiro, 2005).

In Brazil, anthracnose in the mango trees is present in all the productive regions and is one of the greatest phytosanitary problems, especially in fruit exportation. In the Northeast, the main mango cultivation areas are located in the states of Bahia, Pernambuco and Ceará. In the cashew tree cultivation, the disease is widely disseminated in

*Author for correspondence: ilka.tt@gmail.com 
all the cropping areas, and is quite severe in the years with high rainfall, especially during the "cashew rains" at flowering, with a more intensive attack on the blossoms and greater harm to the production (Menezes, 2005).

Considering that the identification of Colletotrichum species or biotypes is nearly always difficult due to enormous variation in the morphology accepted for the different species of the genus, modern techniques have been used to integrate the morpho-physiological, biochemical and molecular methods in taxonomic studies regarding this plant pathogen (Freeman, 2000).

The shape and dimension of the conidia were basic morphological criteria used by Simmonds (1965) and later by Cox and Irwin (1988) for the separation within C. gloeosporioides species. Traditional morpho-physiological methods for differentiating C. gloeosporioides isolates include conidia morphology, appressoria formation, presence or absence of setae, presence or absence of teleomorph, color of colonies, mycelial growth rate and sensitivity to fungicides (Freeman, 2000; Serra and Silva, 2004).

Specific pathogenicity to a particular host, or host group, and cross-infection have also been used to characterize the Colletotrichum species as additional criteria to cultural and morphological characteristics (Arauz, 2000; Afanador-Kafuri et al., 2003). Freeman (2000) reported that a single species of Colletotrichum can infect different hosts. Different Colletotrichum species or biotypes can affect a single host, such as, for example, anthracnose in avocado and mango trees caused by C. gloeosporioides and C. acutatum, and in strawberries caused by $C$. gloeosporioides, $C$. fragariae Brooks and C. acutatum. According to Freeman and Shabi (1996), C. gloeosporioides isolates from an immense range of tropical, subtropical and temperate fruit trees have demonstrated considerable potential for cross infection.

Molecular methods have been used successfully in differentiation between the species and genotypes of Colletotrichum from a high number of hosts. The analysis of the nucleotide sequence of the internal transcribed spacing (ITS) of the ribosomal DNA (rDNA) from genes of $\square$-tubulin 2 (tub2), histone 4 (his4), glutamine synthase (GS), glyceraldehyde-3-phosphate dehydrogenase (GPDH), mytocondrial DNA (mtDNA), RAPD, RFLP and AFLP markers and isozyme analysis have demonstrated the genetic complexity of
Colletotrichum isolates obtained from diverse tropical and temperate fruit trees (Freeman, 2000; Talhinhas et al., 2005).

Reports on the diseases caused by $C$. gloeosporioides in diverse fruit trees have often demonstrated that the fungus exhibits wide phenotypic, genotypic and pathogenic variability (Menezes and Hanlin, 1996a; Afanador-Kafuri et al., 2003; Talhinhas et al., 2005) and consequently, the occurrence of pathogen populations with differentiated behavior can determine variations in the visual aspect of the disease, thereby affecting the adoption of control strategies (Freeman et al., 1998).

In recent years, a number of methods have been proposed to differentiate the species or isolates from a single fungal species, thereby contributing to precise diagnosis through the integration of methods and permitting the detection of forms on a sub-specific or even breed level. Thus, the aim of the present study was to analyze the molecular methods in the differentiation of $C$. gloeosporioides isolates obtained from the cashew and mango trees.

\section{MATERIAL AND METHODS}

\section{Fungal cultures and growth conditions}

The isolates were obtained from the cashew and mango trees from the Northeastern Brazilian states of Maranhão, Pernambuco and Paraíba in mid2003 and codified according to the place of origin, cashew-MA (CMA), cashew-PE (CPE), cashew$\mathrm{PB}$ (CPB), mango-MA (MMA), mango-PE (MPE), and mango-PB (MPB). The fungus was isolated from the leaves with symptoms of anthracnose. Following the routine cleaning and disinfection of the material, fragments from the transition region between the lesion and the healthy tissues (Menezes and Assis, 2004) were transferred to Petri dishes containing a potatodextrose-agar (PDA) and then incubated at $25 \pm 2^{\circ} \mathrm{C}$ in an alternating photoperiod (12h of light / $12 \mathrm{~h}$ of darkness), adopting the method described by Menezes and Assis (2004), and the colonies were kept in tubes containing PDA.

\section{ISOZYME CHARACTERIZATION OF $C$. GLOEOSPORIOIDES ISOLATES}

\section{Fungus culture and protein extracts}


The Colletotrichum isolates were cultivated in $125 \mathrm{ml}$ of the Potato-Dextrose (PD) medium at $25 \pm 2^{\circ} \mathrm{C}$ for six days under a 12-h photoperiod, and gently agitated twice per day.

The mycelia was collected through filtration after two successive rinses with sterile distilled water. Next, 400mg of mycelia were ground in a chilled mortar with the addition of $150 \mathrm{mg}$ of sucrose, $150 \mathrm{mg}$ of polyvinylpyrrolidone and $1.0 \mathrm{~mL}$ of the Tris-glycine buffer $0.125 \mathrm{M}, \mathrm{pH}$ 8.2. After a 12-h resting period, the samples were centrifuged at $14, .000 \mathrm{rpm}$ for six minutes and the protein extracts were kept at $4^{\circ} \mathrm{C}$ (Alfenas et al., 1991).

\section{Preparation of gel plates and electrophoresis}

Polyacrylamide gels (5\%) in a tris-glycine buffer at $0.125 \mathrm{M}, \mathrm{pH} 8.2$, were prepared following the methodology described by Alfenas et al. (1991). After polymerization, the gel was placed in a horizontal tray containing the tris-glycine buffer at $0.125 \mathrm{M}, \mathrm{pH}$ 8.2. Ten microliters of the protein extract from each isolate were applied individually to the gel. Bromophenol blue was used as the marker. Electrophoresis was performed at $4^{\circ} \mathrm{C}$ under a constant current of $10 \mathrm{~mA}$ until the marker line reached $6.5 \mathrm{~cm}$ of the gel.

\section{Detection of isoesterase and total proteins}

To reveal the esterase bands, the gel was immersed in a solution containing $100 \mathrm{~mL}$ of a phosphate buffer $0.1 \mathrm{M}, \mathrm{pH} 6.5,50 \mathrm{mg}$ of $1 \%$-naphtyl acetate and 50mg of fast blue RR for one hour and kept in the dark at $37^{\circ} \mathrm{C}$. To reveal the total proteins, the gel was immersed in a Coomassie blue stain for 12-h, following the technique described by Alfenas et al. (1991).

For the evaluation of the electrophoretic profiles of the isolates, the following parameters were considered: number, color intensity and relative mobility (Rf) of the bands in the polyacrylamide gel, with the latter determined through the formula: $\operatorname{Rf}=(\mathrm{d} / \mathrm{D}) \times 100$, where $\mathrm{d}=$ distance traveled by the molecule, and $\mathrm{D}=$ distance traveled by the stain marker. The genetic similarity between the isolates in the systems studied was determined using the Jaccard coefficient; matrix and genetic clustering analyses were performed using the Unweighted Pair Group Method with Arithmetic Mean (UPGMA) using the NTSYS-pc program.

\section{MOLECULAR CHARACTERIZATION OF COLLETOTRICHUM GLOEOSPORIOIDES ISOLATES}

\section{Extraction and quantification of fungal DNA}

Colletotrichum isolates were cultivated in $150 \mathrm{ml}$ of potato-dextrose (PD) at $25 \pm 2^{\circ} \mathrm{C}$ under a 12 -h photoperiod, with mild agitations twice per day for six days. The DNA from the isolates was extracted from $250 \mathrm{mg}$ of mycelia following the procedure described by Faleiro et al. (2004). Mycelia were collected through the filtration and ground in liquid nitrogen. Next, $700 \mu \mathrm{l}$ a lyse buffer was added (50mM Tris-HCl, pH 8.0; 50mM EDTA; $\mathrm{NaCl} 5 \mathrm{M} ; 3 \%$ sodium dodecyl sulfate (SDS); $1 \%$ $\beta$-mercaptoethanol), followed by 30 minutes of incubation at $70^{\circ} \mathrm{C}$, with agitations every 10 minutes. Then the samples were centrifuged at $14,000 \mathrm{rpm}$ for 10 minutes and a cloroformisoamyl alcohol solution $(25: 1)$ was added. The samples were agitated through gentle inversion and once again centrifuged. The supernatants were transferred to new tubes and the deproteinization process was repeated.

For the precipitation of DNA, $\mathrm{NaCl} 5 \mathrm{M}$ and chilled isopropanol were added to the supernatants. The tubes were kept at $-20^{\circ} \mathrm{C}$ for two hours and afterward centrifuging was repeated. The precipitates were rinsed twice with $70 \%$ ethanol and dried at room temperature. Then the total nucleic acids were re-suspended in $150 \mu$ l of water containing RNAse in a concentration of 40 $\mu \mathrm{g} / \mathrm{ml}$ and placed into a water bath at $37^{\circ} \mathrm{C}$ for one hour for complete re-suspension and digestion of the RNA. The DNA was visually quantified in a $0.8 \%$ agar gel stained in an ethidium bromide solution at $0.05 \mathrm{mg} / \mathrm{l}$ from a comparison with a DNA standard (Low DNA Mass Ladder, Invitrogen).

\section{RAPD analysis}

Amplification reactions followed the methodology proposed by Williams et al. (1990), with the following concentrations: $3 \mathrm{ng} / \mu \mathrm{l}$ genomic DNA, buffer $10 \mathrm{X}, 2 \mathrm{mM} \mathrm{MgCl}_{2}, 200 \mu \mathrm{M}$ of dNTPs, $0.25 \mu \mathrm{M}$ of primer, $1 \mathrm{U}$ Taq DNA polymerase $\left(\right.$ Invitrogen ${ }^{\mathrm{tm}}$ ) and ultra pure water to complete a volume of $15 \mu \mathrm{l}$. Amplifications were performed under the following conditions: one cycle at $94^{\circ} \mathrm{C}$ for 2 minutes; 40 cycles at $94^{\circ} \mathrm{C}$ for 1 minute, 
$40.4^{\circ} \mathrm{C}$ for 1 minute and $72^{\circ} \mathrm{C}$ for 2 minutes; and one cycle at $72^{\circ} \mathrm{C}$ for 7 minutes. A total of 30 previously selected primers were used: OPAA02, OPA04, OPA10, OPA11, OPA12, OPA15, OPA18, OPB10, OPB12, OPB17, OPC08, OPC11, OPC15, OPC20, OPD01, OPD07, OPD15, OPD18, OPT17, OPE02, OPE03, OPE04, OPV08, OPV18, OPV19, OPW06, OPX01, OPX07, PM06 and RC07. The amplification products were separated through electrophoresis in a $1.5 \%$ agar gel at $100 \mathrm{~V}$ and stained in an ethidium bromide solution at $0.05 \mathrm{mg} / \mathrm{ml}$. The band patterns generated were annotated as presence (1) or absence $(0)$ and later converted to a binary matrix. Only the bands that presented adequate definition and were present in both the repetitions performed for each primer and presented lengths in the 400 to $2000 \mathrm{bp}$ range were considered. Genetic similarity was calculated using the Jaccard coefficient. Matrix and genetic clustering analyses were performed using the UPGMA method and the NTSYS-pc software program.

\section{Analysis of the ribosomal DNA ITS region}

The six Colletotrichum isolates obtained from the mango and cashew trees were subjected to PCR reaction with specific primers. For $C$. gloeosporioides, the CgInt primer (5'GACCCTCCCGGCCTCCCGCC-3') was used, and for $C$. acutatum, the CaInt2 primer (5'GGGGAAGCCTCTCGCGG-3') was used (Xiao et al., 2004). Both the primers were used together with the conserved ITS4 universal primer (5'TCCTCCGCTTATTGATATTGC-3').

The amplification reaction was performed following the procedure described by AfanadorKafuri et al. (2003) for a final volume of $25 \mu 1$, containing 10 to $70 \mathrm{ng}$ of genomic DNA, $0.25 \mu \mathrm{M}$ each primer, $200 \mu \mathrm{M}$ of dNTPs, $1.5 \mathrm{mM} \mathrm{MgCl}_{2}$, 1.25 U Taq DNA polymerase (Invitrogen ${ }^{\mathrm{tm}}$ ) and ultra pure water to complete the final volume. Amplification was carried out under the following conditions: one cycle at $95^{\circ} \mathrm{C}$ for 5 minutes; 40 cycles at $95^{\circ} \mathrm{C}$ for 30 seconds, $65^{\circ} \mathrm{C}$ for 30 seconds and $72^{\circ} \mathrm{C}$ for 90 seconds; and one final cycle at $72^{\circ} \mathrm{C}$ for 5 minutes. The amplification products were separated in $1.5 \%$ agar gel in the Trisacetate-EDTA buffer, through horizontal electrophoresis at $80 \mathrm{~V}$ for 2 hours. The gel was stained in an ethidium bromide solution at $0.5 \mathrm{mg} / 1$ and the products were observed under ultraviolet light.

\section{RESULTS AND DISCUSSION}

Protein and isoesterase characterization of Colletotrichum gloeosporioides isolates through electrophoresis in polyacrylamid gel

Between the two systems analyzed in the present study (Table 1), esterase presented a variation from one to three bands, with a predominance of three, in all the isolates, except MPB (mango-PB), which presented only one band (Est 6) with Rf 104.61 of weak intensity. In general, the intensity of the bands varied, demonstrating that the isolates from the cashew had higher isoenzymatic activity (Est3, Est5 and Est6) in relation to the isolates from the mango (Table 1). This activity was characterized by the uniformity in the coloration intensity of the bands. All the isolates, whether from the cashew or mango, presented just one band in common (Est6), and therefore, the same relative mobility of the molecules in the gel ( $\mathrm{Rf}$ =104.61), suggesting that this band was a characteristic of the species C. gloeosporioides.

The protein pattern of the $C$. gloeosporioides isolates also demonstrated variations in the phenotypes exhibited in the polyacrylamid gel. The number of bands ranged from two (isolates from cashew) to three (isolates from mango), with a predominance of medium to weak intensity (Table 1). Regarding the relative mobility (Rf), a difference was clearly observed between the uniformity of the protein pattern presented by the isolates from the cashew: $\operatorname{Pr} 1(\mathrm{Rf}=58.46), \operatorname{Pr} 3(\mathrm{Rf}$ $=69.23)$ and $\operatorname{Pr} 4(\mathrm{Rf}=76.92)$, and that of the isolates from mango: $\operatorname{Pr} 2(\mathrm{Rf}=61.53)$ and $\mathrm{Pr} 4(\mathrm{Rf}$ =76.92). As seen in the isoesterase system, there was the presence of a single common band in the protein system as well ( $\mathrm{Pr} 4)$, with $\mathrm{Rf}=76.92$ for all the isolates analyzed, indicating similarity in the behavior within each system, maintaining a relationship between the isolates revealed by the presence of common bands.

The dendrogram constructed through the NTSYSpc software using the Jaccard coefficient separated the isolates in two groups according to the isoesterase and protein profiles; one group was formed by the isolates from the MPB, MPE and MMA mangos and the second group was made up of the isolates from the CMA, CPE and CPB cashews, which presented $100 \%$ similarity (Fig. 1), demonstrating strict uniformity between the isolates from the cashew in the enzyme systems studied. In C. graminicola, Horvath and Vargas Jr. 
(2004) separated the isolates obtained from four different hosts into two groups by means of isoenzymatic analysis, with isolates from sorghum (Sorghum spp.) and corn (Zea mays L.) presenting differences in genetic distance in comparison to the isolates obtained from Poa апnиa L. and Agrostis palustris Huds., which are species of grass.

Table 1 - Total number, intensity and relative mobility of the esterases bands and total proteins presented by Colletotrichum gloeosporioides isolates.

\begin{tabular}{|c|c|c|c|c|c|c|c|c|c|c|}
\hline \multirow[t]{2}{*}{ Isolates" } & \multirow[t]{2}{*}{$\begin{array}{c}\text { No. of bands / } \\
\text { Esterase }\end{array}$} & \multicolumn{3}{|c|}{ Intensity of the bands } & \multicolumn{6}{|c|}{$\begin{array}{c}\text { Relative mobility } \\
\text { (Rf) }{ }^{1}\end{array}$} \\
\hline & & strong & medium & weak & Est1 & Est2 & Est3 & Est4 & Est5 & Est6 \\
\hline CMA & 3 & 1 & 2 & 0 & & & 70.76 & & 90.76 & 104.61 \\
\hline CPE & 3 & 1 & 2 & 0 & & & 70.76 & & 90.76 & 104.61 \\
\hline CPB & 3 & 1 & 2 & 0 & & & 70.76 & & 90.76 & 104.61 \\
\hline MMA & 3 & 1 & 1 & 1 & 46.15 & 64.61 & & & & 104.61 \\
\hline MPE & 3 & 0 & 3 & 0 & 46.15 & & & 78.46 & & 104.61 \\
\hline \multirow[t]{3}{*}{ MPB } & 1 & 0 & 0 & 1 & & & & & & 104.61 \\
\hline & $\begin{array}{c}\text { No. of bands / } \\
\text { total protein }\end{array}$ & \multicolumn{3}{|c|}{ Intensity of the bands } & \multicolumn{6}{|c|}{$\begin{array}{c}\text { Relative mobility } \\
(\mathbf{R f})^{1}\end{array}$} \\
\hline & & stron & medium & 1 weak & $\operatorname{Pr} 1$ & Pr2 & Pr3 & Pr4 & & \\
\hline CMA & 3 & 0 & 1 & 2 & 58.46 & & 69.23 & 76.92 & & \\
\hline CPE & 3 & 1 & 1 & 1 & 58.46 & & 69.23 & 76.92 & & \\
\hline CPB & 3 & 1 & 1 & 1 & 58.46 & & 69.23 & 76.92 & & \\
\hline MMA & 2 & & 0 & 2 & & 61.53 & & 76.92 & & \\
\hline MPE & 2 & & 1 & 1 & & 61.53 & & 76.92 & & \\
\hline MPB & 2 & & 1 & 1 & & 61.53 & & 76.92 & & \\
\hline
\end{tabular}

"CMA (cashew tree-MA), CPE (cashew tree-PE), CPB (cashew tree-PB), MMA (mango tree-MA), MPE (mango tree-PE), MPB (mango tree-PB).

${ }^{1} \mathrm{Rf}=(\mathrm{d} / \mathrm{D}) \times 100$

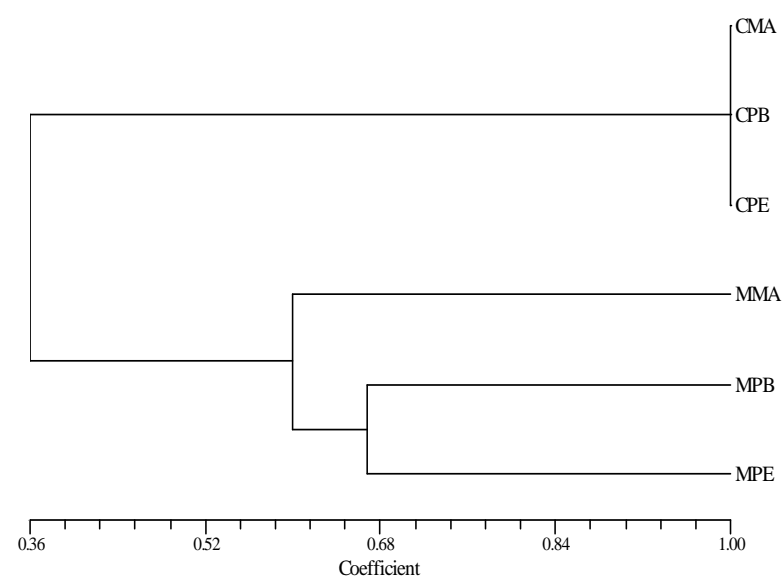

Figure 1 - Dendrogram of Colletotrichum gloeosporioides isolates from cashew and mango trees, based on the isozyme analyses, using the method UPGMA and the coefficient of Jaccard through the program NTSYS-pc.

Several studies have been conducted with the aim of comparing the protein and isoenzymatic patterns to differentiate the species or even differentiate an isolate within a single species of Colletotrichum. Furtado et al. (1999) observed variation in the number, intensity and relative mobility (Rf) of the bands formed in polyacrylamid gel, allowing the visualization of similarity groups between $C$. gloeosporioides isolates obtained from the rubber trees. Kaufmann and Weidmann (1996) verified striking polymorphism between the populations of $C$. gloeosporioides from different hosts and different locations, attributing these results to the 
occurrence of sexual reproduction or some other mechanism of genetic variability. The results from the present study contradicted this, as the isolates that presented the sexual phase (CMA, CPE and $\mathrm{CPB}$ ) exhibited no variability in the isoenzymatic and protein phenotypes.

\section{MOLECULAR CHARACTERIZATION OF COLLETOTRICHUM GLOEOSPORIOIDES ISOLATES}

\section{RAPD analysis}

All the primers tested generated amplification products for the genomic DNA of the $C$. gloeosporioides isolates from the cashew and mango for a total of 293 bands, 255 of which were polymorphic (Table 2 ).

Genetic distance analysis allowed the identification of the CPB and CPE isolates as the genetically closest, with $75 \%$ similarity; and the CMA and MPB isolates as the most distant, with 27\% similarity. As seen in the dendrogram (Fig. 2 ), the isolates were separated in two groups. The first group was made up of the isolates from the MA, PE and PB cashews and the PE mango; the second group was made up of the isolates from the MA and PB mangos. Despite the CMA, CPE and $\mathrm{CPB}$ isolates presenting the sexual form and originating in different locations, they proved to be very close genetically, which was clearly observed in most of the primers used (Fig. 3). In studying the genetic variability of $C$. acutatum in the almonds, Forster and Adasgaveg (1999) observed similar results, as did Freeman et al. (1998) in strawberries; the latter authors observed considerable genetic uniformity among the isolates.

Table 2 - Total of amplified bands and of bands polymorphics and monomorphics goes primer, observed by Colletotrichum gloeosporioides isolates by RAPD.

\begin{tabular}{|c|c|c|c|c|}
\hline \multirow{2}{*}{ Primer } & \multicolumn{2}{|c|}{ bands } & \multirow{2}{*}{ Total $n^{\circ}$. of bands } & \multirow{2}{*}{ Total polymorphism } \\
\hline & Polymorphic & Monomorphic & & \\
\hline$\overline{\mathrm{RC}} 07$ & 5 & 1 & 6 & $83 \%$ \\
\hline PM 06 & 6 & 3 & 9 & $67 \%$ \\
\hline OPX 01 & 12 & 1 & 13 & $92 \%$ \\
\hline OPX 07 & 9 & 1 & 10 & $90 \%$ \\
\hline OPA A02 & 4 & 2 & 6 & $67 \%$ \\
\hline OPA 04 & 10 & 2 & 12 & $83 \%$ \\
\hline OPA 10 & 14 & 2 & 16 & $88 \%$ \\
\hline OPA 11 & 10 & 3 & 13 & $77 \%$ \\
\hline OPA 12 & 4 & 0 & 4 & $100 \%$ \\
\hline OPA18 & 3 & 1 & 4 & $75 \%$ \\
\hline OPB 10 & 10 & 0 & 10 & $100 \%$ \\
\hline OPB 12 & 12 & 0 & 12 & $100 \%$ \\
\hline OPB 17 & 6 & 1 & 7 & $86 \%$ \\
\hline OPC 08 & 4 & 1 & 5 & $80 \%$ \\
\hline OPC 11 & 11 & 3 & 14 & $79 \%$ \\
\hline OPC 15 & 4 & 1 & 5 & $80 \%$ \\
\hline OPC 20 & 7 & 1 & 8 & $88 \%$ \\
\hline OPD 01 & 7 & 1 & 8 & $88 \%$ \\
\hline OPD 07 & 12 & 1 & 13 & $92 \%$ \\
\hline OPD 15 & 8 & 0 & 8 & $100 \%$ \\
\hline OPD 18 & 10 & 2 & 12 & $83 \%$ \\
\hline OPE 02 & 12 & 3 & 15 & $80 \%$ \\
\hline OPE 03 & 9 & 0 & 9 & $100 \%$ \\
\hline OPE 04 & 8 & 0 & 8 & $100 \%$ \\
\hline OPW 06 & 13 & 2 & 15 & $87 \%$ \\
\hline OPV 08 & 9 & 2 & 11 & $82 \%$ \\
\hline OPV 18 & 11 & 2 & 13 & $85 \%$ \\
\hline OPV 19 & 13 & 1 & 14 & $93 \%$ \\
\hline OPT 17 & 6 & 0 & 6 & $100 \%$ \\
\hline Total & 255 & 38 & 293 & \\
\hline
\end{tabular}




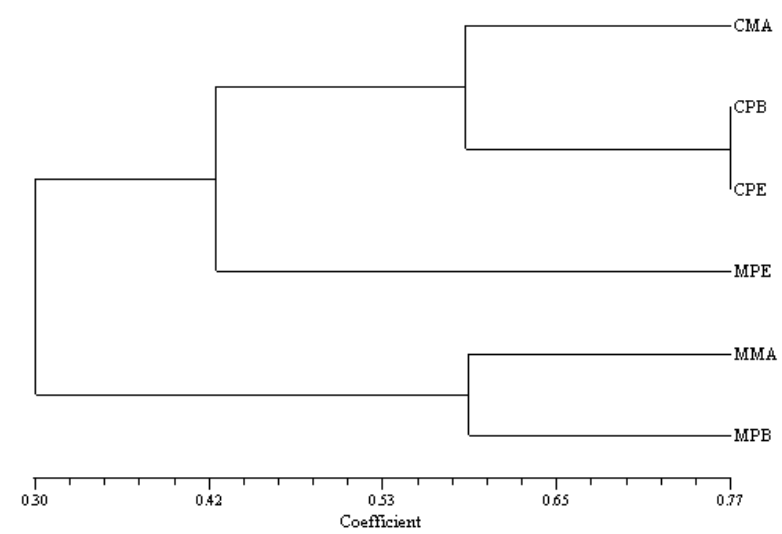

Figure 2 - Dendrogram of Colletotrichum gloeosporioides isolates from cashew and mango trees, based on markers RAPD, using the method UPGMA and the coefficient of Jaccard through the program NTSYS-pc.

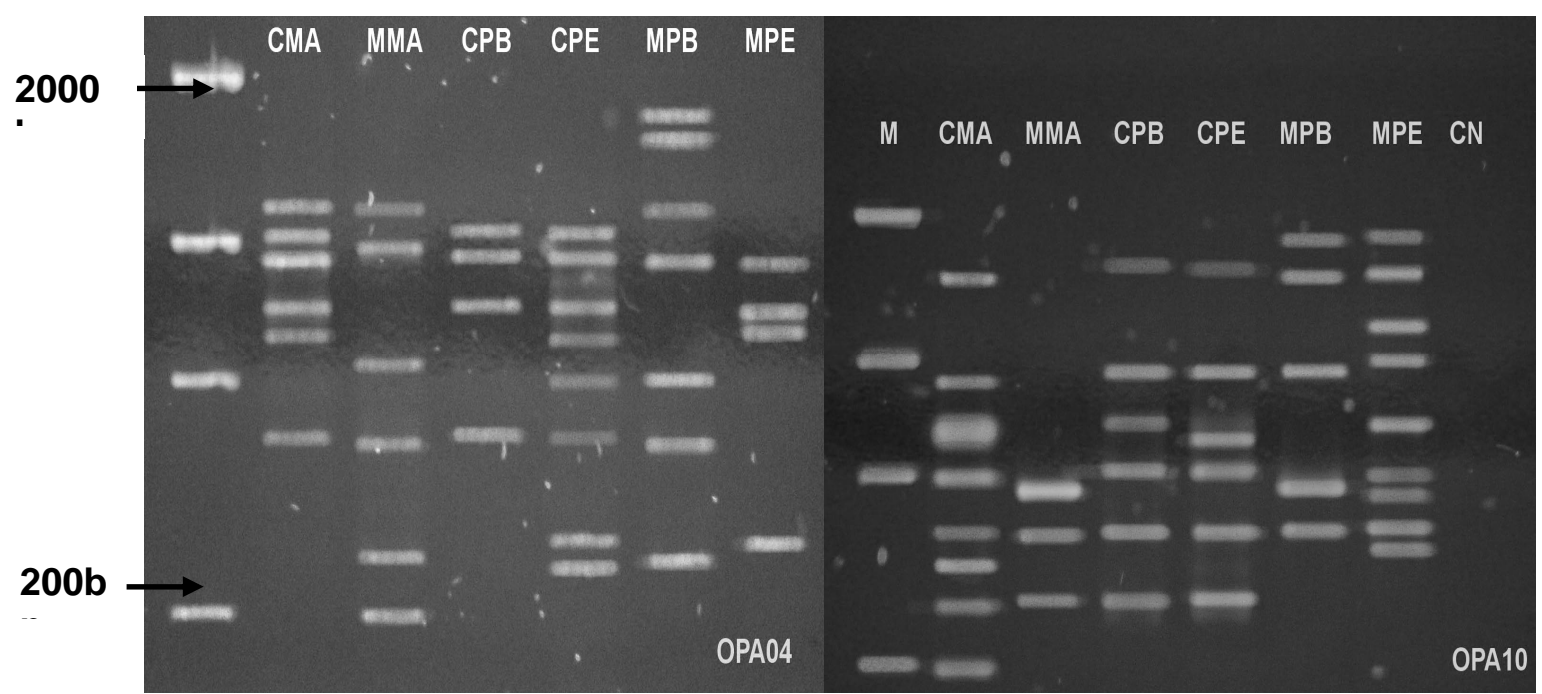

Figure 3 - Products of amplification of genomic DNA of Colletotrichum gloeosporioides isolates from cashew and mango trees, with the RAPD primers.

However, the isolates obtained from the mango exhibited genetic diversity among one another, which might be explained by the different geographic origins. A number of studies have demonstrated the genetic diversity of $C$. gloeosporioides isolates (Bernstein et al., 1995; Freeman et al., 1998; Swart, 1999). In characterizing the Colletotrichum isolates from the tamarind, mango and passion fruit, AfanadorKafuri et al. (2003) observed striking genetic diversity among the isolates from the mango and passion fruit. This genetic heterogeneity could be the result of the presence of the teleomorph phase.

\section{Analysis of the ribosomal DNA ITS region}

The DNA from the Colletotrichum isolates obtained from the cashew and mango was amplified with the primers specific to $C$. gloeosporioides (CgInt) and C. acutatum (CaInt2). All the isolates amplified with the CgInt and ITS4 primers, confirming that the isolates pertained to C. gloeosporioides. The PCR products of the isolates are displayed in Figure 4. Afanador-Kafuri et al. (2003), carried out studies demonstrating that the CaInt 2 and CgInt primers were efficient in differentiating Colletotrichum isolates obtained from the tamarind and mango at the species level 
in $C$. acutatum and C. gloeosporioides. Based on the analysis of the ITS region of the rDNA with the specific primers, the authors were able to confirm that all the isolates obtained from the mango were identified as $C$. gloeosporioides.

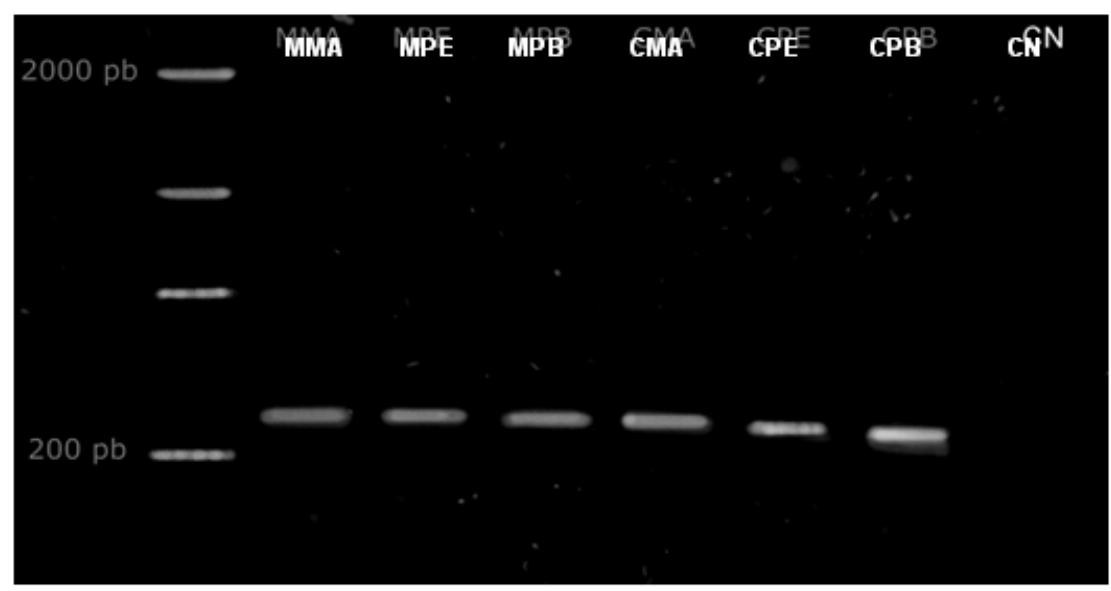

Figure 4 - Amplification of the area ITS and specific identification of Colletotrichum gloeosporioides isolates from cashew and mango trees, using the primer CgInt in combination with ITS4.

The different morphophysiological and molecular methods used in the differentiation of $C$. gloeosporioides isolates from the cashew and mango proved efficient with regard to intraspecific characterization, highlighting sporulation, with the formation of four groups, and mycelial growth and pathogenicity, with the formation of three physiological groups. The analysis of Pearson's correlation between the variables of mycelial growth, growth rate, sporulation and pathogenicity revealed no significance at a 5\% level of probability. Similar results were found by Assis (2001), who verified no significant correlation in the C. gloeosporioides pathosystems from the mango in relation to growth, sporulation and pathogenicity.

Regarding host specificity of the $C$. gloeosporioides isolates obtained from the cashew and mango, pathogenicity was the method that best separated the isolates according to their host. This results corresponded with those obtained from the analyses based on the isoenzymatic systems and RAPD markers. This corroborated the results found by Swart (1999), who observed that pathogenicity and RAPD analysis were the most effective methods in separating the $C$. gloeosporioides isolates from avocado and mango according to host and geographic origin.

\section{REFERENCES}

Abang, M. M.; Hoffman, P.; Winter, S.; Green, K. R.; Wolf, G. A. (2004), Vegetative compatibility among isolates of Colletotrichum gloeosporioides from yam (Dioscorea spp.) in Nigeria. Phytopath, 152, 21-27.

Adaskaveg, J. E.; Forster, H. (2000), Occurrence and management of anthracnose epidemics caused by Colletotrichum species on tree fruit crops in California. In: Prusky, D.; Freeman, S.; Dickman, M.B. (Eds.). Colletotrichum: Host specificity, Pathology and Host-pathogen interaction. pp.317336. St. Paul: APS Press.

Afanador-Kafuri, L.; Minz, D.; Maymon, M.; Freeman, S. (2003), Characterization of Colletotrichum isolates from tamarillo, passiflora, and mango in Colombia and identification of a unique species from the genus. Phytopath, 93, 579-587.

Alfenas, C. A.; Peters, I.; Brune, W.; Passador, G. C. (1991), Eletroforese de proteínas e isoenzimas para identificação de espécies de fungos e essências florestais. $1^{\alpha}$ ed. Viçosa: UFV, pp.242.

Arauz, L. F. (2000), Mango anthracnose: economic impact and current options from integrated management. Plant Dis., 84, 600-611.

Assis, T. C. (2001), Variabilidade de Colletotrichum gloeosporioides, agente causal da antracnose da mangueira, quanto a utilização de carboidratos, patogenicidade, produção de enzimas e analise RAPD. (Tese de Mestrado). Recife. UFRPE 
Bernstein, B.; Zehr, E. I.; Dean, R. A.; Shabi, E. (1995), Characteristics of Colletotrichum from peach, apple, pecan and other hosts. Plant Dis., 79,478-482.

Brooker, N. L.; Leslie, J. F.; Dickman, M. B. (1991), Nitrate non-utilizing mutants of Colletorichum and their use in studies of vegetative compatibility and genetic relatedness. Phytopath, 81,672-677.

Correll, J. C.; Morelock, T. E.; Guerber, J. C. (1993), Vegetative compatibility and virulence of the spinach anthracnose pathogen Colletotrichum dematium. Plant Dis., 77, 688-691.

Cox, M. L.; Irwin, J. A. G. (1988), Conidium and apressorium variation in Australian isolates of the Colletotrichum gloeosporioides group and closely related species. Austr Systm Bot. 1,139-144.

Faleiro, F. G.; Luz, E. D. M. N.; Cerqueira, A. O.; Rocha, C. S. S.; Dantas Neto, A.; Flores, A. B.; Bahia, R. C. S.; Faleiro, A. S. G. (2004), Caracterização e diversidade genética de isolados de Phytophthora spp. do cacaueiro com base em marcadores RAPD. Fito. Bras, 29, 303-306.

Forster, H.; Adaskaveg, J. E. (1999), Identification of subpopulations of Colletotrichum acutatum and epidemiology of almond anthracnose in California. Phytopath., 89, 1056-1065. 1999.

Freeman, S.; Shabi, E. (1996), Cross-infection of subtropical and temperate fruits by Colletotrichum species from various hosts. Physiological and Molecular Plant Path., 49, 395-404.

Freeman, S.; Katan, T.; Shabi, E. (1998), Characterization of Colletotrichum species responsible for anthracnose diseases of various fruits. Plant Dis., 82, 596-605.

Freeman, S. (2000), Genetic diversity and host specificity of Colletotrichum species on various fruits. In: Prusky, D.; Freeman, S.; Dickman, M.B. (Eds.). Colletotrichum: Host specificity, Pathology and Host-pathogen interaction. pp.131-143. St. Paul. APS Press.

Furtado, E.L.; Bach, E.E.; Kimati, H.; Menten, J.O.M.; Silveira, A.P. (1999), Caracterização morfológica, patogênica, e isoenzimática de isolados de Colletotrichum gloeosporioides de seringueira. Summa Phyto, 25, 222-228.

Gutierrez, G.J.A.; Nieto, D.A.; Teliz, D.O.; Zavaleta, E.M.; Vaquera, H.H.; Martinez, T.D.; Delgadilho, F.S. (2001) Characteristics de crecimiento, germination, sporulation and pathogenicity of Colletotrichum gloeosporioides Penz. isolates obtained from mango (Mangifera indica L.) fruit. Rev Mexicana de Fito., 19, 90-93.
Horvath, B.J.; Vargas JR., J.M. (2004), Genetic variation among Colletotrichum graminicola isolates from four hosts using isozyme analysis. Plant Dis., 88, 402-406.

Kaufmann, P.J.; Weidemann, G.J. (1996), Isoezyme analysis of Colletotrichum gloeosporioides from five host genera. Pl. Dis., 80, 1289-1293.

Lilly, V.G.; Barnett, H.L. Physiology of the fungi. New York: McGraw-Hill. 1951: 464p.

Menezes, M.; Hanlin, R.T. (1996a), Morphological variability of Colletotrichum gloeosporioides isolates from avocado trees from Northeastern Brazil. Rev. de Microbio., 27, 228-236.

Menezes, M.; Hanlin, R.T. (1996b), Apressoria of Brazilian isolates of Colletotrichum gloeosporioides (Penz.) Sacc. causal agent of anthracnoses diseases. Rev. de Microbio., 27, 247-251.

Menezes, M.; Assis, S.M.P. (2004), Guia prático para

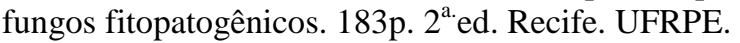

Menezes, M. (2005), Doenças do cajueiro. In: Kimati, H. et al. (Eds.) Manual de Fitopatologia: Doenças de plantas cultivadas. pp.181-184. $4^{\mathrm{a}}$ ed. São Paulo, Editora Ceres.

Ribeiro, I.J.A. (2005), Doenças da mangueira. In: Kimati, H. et al. (Eds.) Manual de Fitopatologia: Doenças de plantas cultivadas. pp.457-465. $4^{\text {a }}$ ed. São Paulo, Editora Ceres.

Serra, I.M.R.S.; Silva, G.S. (2004), Caracterização morfofisiológica de isolados de Colletotrichum gloeosporioides agentes de antracnose em frutíferas no Maranhão. Summa Phyto., 30, 475-480.

Simmonds, J.H. (1965), A study of the species of Colletotrichum causing ripe fruits rots in Queensland. Journal of Agricultural and Animal Science, 22, 437459.

Swart, G.M. Comparative study of Colletotrichum gloeosporioides from avocado and mango. (Ph.D Thesis). Pretoria. Faculty of Biological and Agriculture Sciences/ University Pretoria. 1999.

Talhinhas, P.; Screenivasaprasad, S.; Neves-Martins, J.; Oliveira, H. (2005), Molecular and phenotypic analyses reveal the association of diverse Colletotrichum acutatum groups and a low level of $C$. gloeosporioides with olive anthracnose. Applied and Enviro. Micro., 71, 2987-2998.

Várzea, V.M.P.; Rodrigues JR., C.J.; Lewis, B.G.(2002), Distinguishing characteristics and vegetative compatibility of Colletotrichum kahawe in comparison with other related species from coffee. Plant Path., 51, 202-207. 
Xiao, C.L.; Mackenzie, S.J.; Legard, D.E. (2004), Genetic and pathogenic analyses of Colletotrichum gloeosporioides isolates from strawberry and noncultivated hosts. Phytopath., 94, 446-453.
Williams, J.G; Kubelik, A.R.; Livak, K.J.; Rafalski, L.A.; Tingey, S.V. (1990), DNA polymorphism amplified by arbitrary primers are useful as genetic markers. Nucleic Acids Research, 18, 6531-6535.

Received: August 05, 2010;

Revised: March 21, 2011; Accepted: September 12, 2011. 